\title{
Mode of Action of Plant Hormones and Plant Growth Regulators During Induction of Somatic Embryogenesis: Molecular Aspects
}

\author{
Clément Thomas ${ }^{1}\left(\right.$ Víctor M. Jiménez $^{2}$ \\ ${ }^{1}$ Plant Molecular Biology, CRP-Santé, Bâtiment modulaire, \\ 84 Val Fleuri, 1526 Luxembourg, Luxembourg \\ clement.thomas@crp-sante.lu \\ ${ }^{2}$ CIGRAS, Universidad de Costa Rica, 2060 San Pedro, Costa Rica \\ vjimenez@cariari.ucr.ac.cr
}

\begin{abstract}
Plant hormones play critical roles in the establishment of somatic embryogenesis. During this process, somatic plant cells reverse their state of differentiation, acquire pluripotentiality and set up a new developmental program. The identification of the regulatory mechanisms that govern the key events of somatic embryogenesis requires molecular and genetic investigations. One critical issue is how plant hormones and growth regulators act to mediate somatic embryogenesis. Do they function as simple stimuli or participate directly, as central signals, in the reprogramming of the somatic cells towards an embryogenic fate? The latter scenario is now well supported by a number of studies that provide evidence of close interconnections between plant hormones and the molecular pathways that control somatic embryogenesis, including chromatin remodeling, gene expression patterning, reactivation of cell cycle and division and regulation of protein turnover. In this chapter we describe recent advances in the understanding of molecular and genetic mechanisms underlying the early stages of somatic embryogenesis. The roles and mode of action of plant hormones are especially emphasized.
\end{abstract}

$\begin{array}{ll}\text { Abbreviations } & \\ \text { 2,4-D } & \text { 2,4-Dichlorophenoxyacetic acid } \\ \text { ABA } & \text { Abscisic acid } \\ \text { ABP1 } & \text { Auxin binding protein 1 } \\ \text { ARF } & \text { Auxin-response factors } \\ \text { aza-C } & \text { 5-Azacytidine } \\ \text { BBM } & \text { BABY BOOM } \\ \text { BAP } & \text { Benzylaminopurine } \\ \text { CDK } & \text { Cyclin-dependent kinase } \\ \text { DD-RT PCR } & \text { Differential display reverse transcription polymerase chain reaction } \\ \text { ER } & \text { Endoplasmic reticulum } \\ \text { GA } & \text { Gibberellin } \\ \text { IAA } & \text { Indole-3-acetic acid } \\ \text { LEC } & \text { LEAFY COTYLEDON } \\ \text { NAA } & \text { Naphthalene acetic acid } \\ \text { PGR } & \text { Plant growth regulator }\end{array}$




$\begin{array}{ll}\text { PH } & \text { Plant hormone } \\ \text { PKL } & \text { PICKLE } \\ \text { SE } & \text { Somatic embryogenesis } \\ (\text { SERK }) & \text { SOMATIC EMBRYOGENESIS RECEPTOR-LIKE KINASE } \\ (\text { WUS }) & \text { WUSCHEL }\end{array}$

\section{1}

\section{Introduction}

Somatic embryogenesis (SE) has been observed to be induced by different factors (reviewed by Jiménez 2001; Fehér et al. 2003). Independently of the nature of the external stimulus, the establishment of SE necessarily involves profound changes at the molecular level, such as the coordinated expression of different sets of genes that drive the switch from the current vegetative growth pattern to an embryogenic development. Thus, the identification of the genes that trigger key phases of SE, i.e. cell dedifferentiation, cell cycle reentry and establishment of a new embryogenic fate, is highly desirable. Additionally, the elucidation of the signaling pathways by which plant cells remodel their gene expression program is central to understanding the regulation of the SE process.

As discussed in detail elsewhere (Jiménez and Thomas, this volume), plant growth regulators (PGRs) are among the external stimuli most often employed to induce SE and to regulate the further development of embryogenic tissues. There was some controversy as to whether PGRs/plant hormones (PHs) act only as stimuli or are more directly involved in the mechanisms that regulate gene expression (Gaspar et al. 2003). However, during the last few years, a large body of experimental data supports the view that PHs play a central role in the establishment of SE. The understanding of the underlying mechanisms of $\mathrm{PH}$ action requires investigation of hormone receptors, signal transduction pathways, and genetic programs that lead to the final cell response.

The first step in any event associated with a response to a hormone is a proper recognition by the target cells. This recognition normally involves receptors, which are proteins associated with the cell membranes or are located in the cytoplasm. Receptors have been identified and characterized for hormone groups such as ethylene (Chang et al. 1993; Schaller and Bleecker 1995) and cytokinins (Inoue et al. 2001; Ueguchi et al. 2001). These receptors activate a signal transduction pathway that either induces or inhibits cellular functions, or controls gene expression (reviewed by Kulaeva and Prokoptseva 2004).

In the case of auxins, although some auxin-binding proteins have been isolated, it is still uncertain whether they represent receptors for different auxin-mediated processes (Gaspar et al. 2003). To date, auxin binding pro- 
tein 1 (ABP1) is the best-studied putative auxin receptor protein. ABP1 predominantly accumulates in the lumen of the endoplasmic reticulum (ER), an unusual location for a hormone receptor (Barbier-Brygoo et al. 1989; Inohara et al. 1989). However, there is evidence that ABP1 is active in auxin responsiveness at the surface of the plasma membrane although it carries the ER retention motif (Rück et al. 1993; Thiel et al. 1993; Leblanc et al. 1999; Steffens et al. 2001; Shimomura et al. 1989). ABP1 has been shown to mediate early auxin responses such as auxin-induced electrical responses (Rück et al. 1993; Thiel et al. 1993; Zimmermann et al. 1994; Bauly et al. 2000) and cell expansion (Jones et al. 1998; Chen et al. 2001a, b). However, its involvement in auxin-induced gene expression has not been proved yet. Although mechanisms responsible for auxin signal transduction from receptor to genome are still poorly known, significant progress has been achieved in auxin-regulated gene expression (reviewed by Hagen and Guilfoyle 2002).

The PGRs most widely used to induce and regulate in vitro SE are auxins and cytokinins. It has been observed that members from both hormone groups regulate the cell cycle and trigger cell divisions (Francis and Sorrell 2001), two very important factors that have been related to initiation of SE (Dudits et al. 1991, 1995; Yeung 1995). Recent data provide evidence that the elaboration and execution of developmental programs require a proper control of the cell cycle and division, indicating the regulators of the cell cycle machinery as key determinants of SE.

In addition to their influence on cell cycle progression, PGRs/PHs have been demonstrated to trigger substantial changes in chromatin structure and alteration of transcription that lead to the formation of either dedifferentiated callus tissues or somatic embryos (Dudits et al. 1995). Studies on the links between $\mathrm{PH}$ action and gene expression have resulted in the cloning of several genes responsive to auxins, cytokinins, or to both hormones. Although, the functions of a number of these genes remain unknown, others have obvious connections with the cell cycle or developmental processes including SE.

In this chapter we describe those findings related to cell division and changes in the pattern of gene expression during early stages of SE and we further highlight how hormonal signals are integrated into these processes.

\section{2}

\section{Reactivation of Cell Cycle and Division}

The reactivation of the cell cycle and division in differentiated cells is indispensable for the initiation of plant developmental processes, including SE (Dudits et al. 1995). The cell cycle is usually divided in four sequential phases: G1, S (DNA replication), G2 and M (cytokinesis). The basic control mechanisms that regulate progression through the cell cycle are remarkably well conserved during evolution and operate mainly at the G1-S and G2-M tran- 
sitions (reviewed by Stals and Inzé 2001; De Veylder et al. 2003; Dewitte and Murray 2003). These two key check points depend on highly conserved serine/threonine kinases, named cyclin-dependent kinases (CDKs), and their associated regulatory subunits called cyclins.

The two mentioned groups of hormones, auxin and cytokinins, are generally sufficient to stimulate and sustain the in vitro proliferation of most plant cell types and have therefore been the best documented direct regulators of the cell cycle progression. The expression of genes related to the $c d c 2$ gene, which encodes the catalytic subunit of the key G1-S and G2-M regulator cdc2 protein kinase, is upregulated by auxin in alfalfa (Hirt et al. 1991), soybean (Miao et al. 1993) and tobacco pith explants (John et al. 1993). Although auxin enhances $c d c 2$ gene expression, cotreatment with cytokinin is absolutely required to induce a basic $c d c 2$ expression in tobacco pith explants (John et al. 1993), illustrating the synergic regulation exerted by both growth regulators on cell proliferation. The observation that most systems require only exogenously added auxin to resume cell division suggests that the rate of endogenous cytokinin synthesis is sufficient to sustain growth (del Pozo et al. 2005). In situ analysis of $c d c 2$ expression in plants such as Arabidopsis (Martinez et al. 1992; Hemerly et al. 1993) and soybean (Miao et al. 1993) revealed that $c d c 2 a$ expression is not only associated with cell proliferation but also precedes it, suggesting that it reflects a state of competence to divide (Hemerly et al. 1993).

More recently, auxin has been shown to upregulate the expression of an alfalfa A2-type cyclin, whose promoter contains auxin-response-like elements (Roudier et al. 2003). In addition, auxin treatment of alfalfa plants affects the spatial expression pattern of this cyclin by shifting its expression from the phloem to the xylem poles, where lateral root formation is initiated in response to auxin. This auxin-regulated spatial cyclin expression illustrates another aspect of the complexity of hormonal regulation of the cell cycle in planta.

Cyclins D represent important connections between PHs and the cell cycle. Consistent with its regulatory function in the cell cycle progression, cyclin CycD3 is expressed in tissues having a high rate of cell divisions, including shoot meristems, young leaf primordia, axillary buds, procambium and vascular tissues of developing leaves (Riou-Khamlichi et al. 1999). The CycD3 gene is highly responsive to cytokinin in both cell cultures and whole plants and is rapidly induced by cytokinin during the G1 phase of cells reentering the cell cycle. Constitutive expression of this cyclin in transgenic Arabidopsis plants leads to diverse disorders, e.g., extensive leaf curling and disorganized meristems, and, importantly, it renders callus growth independent of cytokinin application (Riou-Khamlichi et al. 1999). This demonstrates that cytokinins promote cell division by inducing the $C y c D 3$ expression at the G1-S phase transition.

Cytokinins have also been reported to play a regulatory role at the mitotic control point of the G2-M transition. This is well illustrated by the observa- 
tion that application of the cytokinin biosynthesis inhibitor lovastatin blocks cells of tobacco BY-2 in G2 (Laureys et al. 1998). This effect is nullified by the addition of an exogenous cytokinin, such as zeatin. This is in line with previous observations that cytokinins accumulate transiently during the G2-M phase (Redig et al. 1996) and that the removal of cytokinin from the culture medium leads to an arrest in G2 of tobacco suspension cell cultures, which accumulate inactive CDK complexes (Zhang et al. 1996). The kinase activity of the latter is restored by either addition of cytokinin or by tyrosine dephosphorylation, suggesting that the inactivation of CDK complexes under cytokinin deprivation is due to phosphorylation of regulatory residues of the CDK subunit.

Although auxin and cytokinins are generally considered as the main hormonal signals triggering cell cycle progression, others $\mathrm{PHs}$ with enhancing or inhibitory functions participate in the cell cycle control by modulating the transcriptional expression of different cell cycle genes. For example, gibberellin (GA) stimulates CDK and cyclin accumulation in a tissue-specific manner (Sauter 1997). Abscisic acid (ABA) induces a decrease in Cdc2a-like kinase activity by increasing the expression level of a CDK inhibitor gene, namely the ICK1 gene, whose product interacts with Cdc2a and CycD3 (Wang et al. 1998). Although its mode of action is still unclear, jasmonic acid has been reported to block synchronized BY2 cells in both G1-S and G2-M transitions (Swiatek et al. 2002).

\section{3}

\section{Reprogramming of the Gene Expression Pattern}

The establishment of totipotency and the subsequent induction and development of somatic embryos require reprogramming the cultures. This is in part achieved by synthesis of new RNA molecules. Therefore, early inductive molecular events have been investigated by monitoring gene transcripts that are synthesized under the influence of external stimuli that trigger the embryogenic fate. Several examples of changes in the expression of genes related to initiation of SE have been reported. Here, we make reference only to those works in which the change in gene expression can be traced back to PGRs/PHs.

In an attempt to identify genes that switch on the SE program, researchers have employed systematic approaches aimed at comparing the population of transcripts expressed in embryogenic conditions with the population of the transcript expressed in nonembryogenic conditions. This was carried out using techniques such as differential complementary DNA library screening, differential display reverse transcription polymerase chain reaction (DD-RT PCR), cold plaque screening and more recently microarrays. The application of these techniques to the induction phase of SE has been complicated by the 
difficulty to identify and isolate embryogenic cells in the initial steps when no morphological changes are visible. However, improvements in in vitro culture systems and methods of molecular analysis have allowed progress in the exploration of the early phases of SE.

Nagata et al. (1994) isolated three auxin-regulated genes, parA, parB and $\operatorname{par} C$, that are transiently expressed during the regaining of meristematic activity of tobacco mesophyll protoplasts. The corresponding transcripts were detected as early as 20 min after the beginning of incubation of protoplasts with auxin. Importantly, they were no longer detected after $48 \mathrm{~h}$ of culture when protoplasts started to divide, suggesting that they are specifically involved in the reentry into the plant cell cycle.

Kitamiya et al. (2000) isolated two carrot genes that are differentially expressed in hypocotyl cells induced to form somatic embryos by treatment with 2,4-dicholorophenoxyacetic acid (2,4-D) for $2 \mathrm{~h}$. One of these genes, namely the $D$. carota heat-shock protein 1 (Dchsp-1) gene, is related to low molecular weight heat-shock proteins and was found to be expressed during embryo development. The other gene has homology to the auxin-regulated genes, including par A (Takahashi et al. 1989), and thus was named D. carota auxin-regulated gene 1 (Dcarg-1). Interestingly, there is a parallel relationship between the expression of Dcarg-1 and the formation of somatic embryos. In addition, in contrast to Dchsp-1, Dcarg-1 was not responsive to stress treatment and was not expressed during development of somatic embryos, implying that its function was not required for this process to occur.

Using DD-RT PCR, Yasuda et al. (2001) attempted to identify genes that are preferentially expressed during the early stages of auxin-induced carrot SE. Three transcripts that accumulate immediately after somatic cells divide to form cell clusters, but that do not accumulate or barely accumulate in nonembryogenic cell suspension cultures, were characterized. Although these genes represent potential key regulators of SE, a clear function has still not been attributed to them.

An important issue is how $\mathrm{PH}$ action on the gene expression level pattern is mediated. In a general view, the hormonal signal activates a signaling cascade that recruits specific transcription factors. These induce the expression of target genes, which in turn trigger the final response. Numerous genes have been described containing cis-acting elements in their promoter region that confer hormone responsiveness. Over the past 20 years, sequences that are upregulated or downregulated by PHs have been described for auxins (Guilfoyle et al. 1998; Ulmasov et al. 1999), ABA (Marcotte et al. 1992), GAs (Gubler and Jacobsen 1992) and ethylene (Meller et al. 1993).

The auxin-modulated gene expression system is based, at least in part, on two interacting protein families. The multifamily protein auxin-response factors (ARFs) can activate or repress target genes by directly binding to specific DNA sequences, i.e., auxin response elements (Ulmasov et al. 1999). In contrast, the auxin/indole-3-acetic acid (IAA) proteins do not bind to DNA 
directly but can inactivate ARF transcription factors by interacting with them through heterodimerization (Tiwari et al. 2001). Auxin exerts its regulation on gene expression through modulation of auxin/IAA protein turnover via a specialized branch of the ubiquitin-proteasome pathway (Worley et al. 2000; Gray et al. 2001; Dharmasiri and Estelle 2002). Such a PH-regulated proteolysis has been shown to be involved in many aspects of plant developmental processes including SE.

\section{4}

\section{Chromatin Structure and DNA Methylation}

A specific gene expression program is the result of the balance between the part of the genome that is transcribed, i.e., euchromatin, and the part that is repressed, i.e., heterochromatin. Many aspects of plant development, including embryonic and meristem development, flowering and seed formation, involve modifications of chromatin structure that affect the accessibility of target genes to regulatory factors that control their expression (reviewed by Li et al. 2002). Since maintaining the cellular differentiated state largely relies on chromatin-dependent gene silencing, the cellular dedifferentiation and the switch to a new embryogenic program necessarily involve important changes in chromatin structure.

Zhao et al. (2001) identified two distinct phases of chromatin decondensation during in vitro induced dedifferentiation of tobacco mesophyll cells. The first was independent of any hormonal treatment and was linked to the acquisition of pluripotentiality or dedifferentiation of cells. In contrast, the second phase of chromatin decondensation required auxin and cytokinin treatment and was linked to the reentry into the $\mathrm{S}$ phase.

Dynamic changes in chromatin structure are influenced by both posttranslational modifications of histone amino terminal tails and direct modifications of the DNA, such as methylation. The degree of DNA methylation has been reported to influence plant morphogenesis (reviewed by Li et al. 2002). The overexpression of an antisense DNA methyltransferase copy in transgenic tobacco plants provokes development disorders, including small leaves, short internodes and abnormal flower morphology (Nakano et al. 2000). The role of DNA methylation in early phases of SE has been recently addressed by Yamamoto et al. (2005) by investigating the effects of 5-azacytidine (aza-C), an inhibitor of DNA methylation, on the induction of direct carrot SE. Aza-C treatment totally inhibited the formation of embryogenic cell clumps from epidermal carrot cells. When applied during morphogenesis of embryos, aza-C downregulated the expression of $C-L E C 1$, an important gene that participates in the embryonic program (Sect. 6). Additionally, in untreated cells, a DNA methyltransferase gene transcript transiently accumulated after auxin application but before the formation of embryogenic cell clumps, suggest- 
ing a direct role for DNA methylation in the establishment of embryogenic competence in carrot somatic cells.

Other chemical substances, such as the antibiotic kanamycin, have been observed to considerably modify the level of DNA methylation during plant in vitro culture (Bardini et al. 2003). In this case, DNA methylation is considered as a potential source of somaclonal variation, a phenomenon (often undesirable) observed in plant cell and tissue cultures (Caplan et al. 1998).

\section{5}

\section{Some Key Regulators of the Vegetative-to-Embryogenic Transition}

As already stated, different strategies have been used to identify genes that are differentially expressed during SE (Thomas 1993; Lin et al. 1996; Schmidt et al. 1997). Although several genes have been cloned, their function or functions often remain obscure. However, improvements in plant transformation protocols and the availability of new mutants allowed the characterization of genes that regulate the vegetative-to-embryogenic transition. The ectopic expression of these genes either enhances SE in in vitro cultures or even provokes spontaneous embryo formation on intact plants. One new challenge is to identify possible existing links between the $\mathrm{PRG} / \mathrm{pH}$ and the genes that possibly influence the vegetative-to-embryogenic transition during SE.

\section{1}

\section{The SOMATIC EMBRYOGENESIS RECEPTOR-LIKE KINASE Gene}

Most of the molecular markers of SE identified to date are related to late stages of embryo development. However, one gene, encoding a leucine-richrepeat receptor-like kinase, has been found to be specifically upregulated during the very precocious phases of the SE process. The SOMATIC EMBRYOGENESIS RECEPTOR-LIKE KINASE (SERK) gene was originally cloned from a carrot cell suspension culture where it was found to mark cells that are competent to form somatic embryos, i.e., cells in transition between the somatic and the embryogenic states (Schmidt et al. 1997). Using in situ hybridization, $D C S E R K$ expression was shown to first appear in single cells of embryogenic cultures induced with 2,4-D for 7 days. DcSERK expression continues until the 100-cell stage of the globular somatic embryo and then ceases. Interestingly, a similar SERK expression pattern was observed during early zygotic embryogenesis, suggesting that the same SERK signaling pathway is activated during both SE and zygotic embryogenesis (Schmidt et al. 1997).

Several homologs of the carrot DCSERK have been identified in monocots, e.g., maize (Baudino et al. 2001) and Dactylis glomerata (Somleva et al. 2000), and dicots, e.g., Medicago truncatula (Nolan et al. 2003), Arabidopsis thaliana (Hecht et al. 2001) and sunflower (Thomas et al. 2004). Plant 
genomes contain several SERK genes. As an example, the Arabidopsis SERK gene family comprises five members (Hecht et al. 2001). The expression of AtSERK1, the Arabidopsis gene most closely related to the carrot DcSERK, also marks embryogenic competent cells in culture. As in carrot, the level of $S E R K$ expression increases in response to the auxin treatment used to induce somatic embryos. Auxin-dependent SERK expression was also reported for the M. truncatula MtSERK gene, which is upregulated by the auxin naphthalene acetic acid (NAA) but not by the cytokinin benzylaminopurine (BAP; Nolan et al. 2003). However, addition of BAP to the culture medium potentiates NAA-induced SERK expression, possibly by stimulating endogenous auxin synthesis. In the direct SE system of sunflower, SERK transcripts specifically accumulate in the future morphogenic region of explants within the first few hours of culture. Although the only PGR supplied in the medium is a cytokinin, analysis of the endogenous $\mathrm{PH}$ content revealed that the internal IAA concentration transiently increases in explants during this early period (Thomas et al. 2002). A link between auxin and SERK expression is also suggested by the accumulation of SERK transcripts in plant tissues that contain high auxin levels, e.g., vascular tissue and leaf primordia (Hecht et al. 2001; Thomas et al. 2004). However, since SERK is not induced by auxin in all the cell explants or cell cultures, it is probably not an integral part of the auxin machinery or its expression requires other, still unknown, factors (Hecht et al. 2001).

Evidence that AtSERK1 is not only a good marker of embryogenic competent cells in Arabidopsis but is also involved in the establishment of the embryogenic competence comes from ectopic overexpression of the AtSERK1 gene in Arabidopsis (Hecht et al. 2001). Although during normal growth transgenic seedlings do not show any specific phenotype, their embryogenic capacity is considerably enhanced (approximately 4 times compared with the wild type) during in vitro culture. A similar increase in embryogenic competence is conferred by mutation in shoot apical meristem regulatory genes such as AMP1, CLV1 and CLV2 (Mordhorst et al. 1998). The higher AtSERK1 expression level in amp1 cultures, in comparison with that in wild-type cultures, suggests that one role of AMP1 could be to downregulate the expression of AtSERK1 after germination (Hecht et al. 2001).

The identification of SERK-activating ligand(s) as well as the downstream targets of SERK is highly desirable to further characterize the function(s) of SERK in both zygotic embryogenesis and SE.

\section{2}

\section{The $B A B Y B O 0 M$ Gene}

Another gene that potentially activates signal transduction pathways leading to the induction of embryo development from differentiated somatic cells is the $B A B Y B O O M(B B M)$ gene (Boutilier et al. 2002). It was identified 
by a screening approach aimed at identifying genes differentially expressed during early phases of Brassica napus microspore embryogenesis. The B. napus microspore culture system relies on the ability of the vegetative cell of an immature pollen grain to develop into an embryo in response to hightemperature (above $25^{\circ} \mathrm{C}$ ) culture conditions (Custers et al. 1994).

The $B B M$ gene encodes a protein that belongs to the AP2/ERF family, a plant-specific class of transcription factors that regulate several developmental processes, such as floral organ identity determination and control of leaf epidermal cell identity (reviewed by Riechmann and Meyerowitz 1998). It is preferentially expressed during embryo and seed development (Boutilier et al. 2002).

Overexpression of the $B B M$ gene under the control of a constitutive promoter leads to the spontaneous formation of somatic embryos and cotyledonlike structures on different tissues of intact plants (Boutilier et al. 2002). Additionally, in vitro cultured explants, coming from $B B M$-overexpressing transgenic plants, display an enhanced capacity to regenerate through shoot organogenesis. This suggests that $B B M$ plays a broader role in cell division and differentiation rather than being a specific element of the SE pathway.

Importantly, in contrast to $S E R K$, ectopic expression of $B B M$ is able to promote SE in the absence of exogenously applied PGR. It has been proposed that $B B M$ could act by stimulating an increase of $\mathrm{PH}$ and/or increasing the cellular hormonal sensitivity (Boutilier et al. 2002). In that sense, Klucher et al. (1996) speculated that AP2/ERF domain proteins, being unique to plants, might have coevolved with plant-specific pathways such as $\mathrm{PH}$ signal transduction. Alternatively, it is also conceivable that the $B B M$ product acts in a $\mathrm{PH}$ signaling pathway downstream of the hormone perception as previously shown for some other AP2/ERF domain proteins (Finkelstein et al. 1998; Menke et al. 1999; Gu et al. 2000; Banno et al. 2001; van der Fits and Memelink 2001).

\section{3}

\section{The LEAFY COTYLEDON Genes}

Arabidopsis mutants that display abnormalities in embryo development represent powerful tools to investigate the molecular pathways underlying SE. The LEAFY COTYLEDON1 (LEC1) and LEAFY COTYLEDON2 (LEC2) genes were identified originally as loss-of-function mutants showing defects in both embryo identity and seed maturation processes (Meinke et al. 1994; West et al. 1994). Lec embryos present a reduction in desiccation tolerance and do not accumulate normal storage materials. In addition, lec mutants exhibit other anatomical characteristics, including the presence of trichomes on cotyledons, which in Arabidopsis wild-type plants are specific to true leaves (Meinke et al. 1994; West et al. 1994; Stone et al. 2001). The pleiotropic effects of lec mutations pinpoint the LEC genes as central regulators of embryo and seed development. 
Identification and analysis of the Arabidopsis LEC1 and LEC2 genes confirmed their regulatory roles in embryogenesis and provided significant insight into their functions. Both $L E C$ genes encode seed-expressed transcriptional activators. $L E C 1$ encodes a protein related to the heme-activated protein 3 subunit of the CCAAT box-binding factor, a eukaryotic transcription factor (Lotan et al. 1998). LEC2 encodes a protein that contains the plantspecific B3 domain (Stone et al. 2001), which is found in several plant transcription factors including ABA INSENSITIVE3 (Luerssen et al. 1998) and VIVIPAROUS1 (McCarty et al. 1989 and 1991).

Ectopic overexpression of either lec1 or lec2 results in the spontaneous formation of somatic embryos directly on the leaf surface, suggesting that lec genes play a role in conferring embryogenic competence to cells (Lotan et al. 1998; Stone et al. 2001). It also confers embryonic characteristics to seedlings. The expression of embryo-specific genes, such as those encoding cruciferin A, 2 S storage protein and oleosin, in adult transgenic seedlings, confirms the activation and maintenance of embryo-specific programs in vegetative tissues. Interestingly, the $35 S:: L E C 1$ phenotype is relatively weak, i.e., only a few plants show sporadic embryo development, whereas the 35S::LEC2 phenotype is stronger and comparable to that observed for $35 S:: B B M$ plants. The fact that the $B B M$ and $L E C$ genes exhibit similar putative functions as transcription factors, are both preferentially expressed in seeds, and confer to plants a similar phenotype when ectopically expressed suggests that they function in the same molecular pathway. However, $B B M$ transcripts are present in lec1 mutant seeds (Boutilier et al. 2002), indicating that the expression of $B B M$ is not dependent per se on the presence of the $L E C 1$ protein. Thus, $B B M$ could either function upstream of $L E C 1$ or operate in an $L E C 1$-separated but overlapping pathway.

Recently, Yazawa et al. (2004) isolated a carrot functional homolog of Arabidopsis $L E C 1$, as demonstrated by complementation experiments. In the SE system of carrot, the highest expression of C-LEC1 was detected in cell clusters of $38-63 \mu \mathrm{m}$ in diameter that were being cultured for induction of somatic embryos. Strikingly, cell clusters of this size are also those that are the most efficient for somatic embryo production (Satoh et al. 1986).

\section{4 \\ The PICKLE Gene}

Another interesting Arabidopsis mutant is the pickle ( $p k l)$ mutant described by Ogas et al. (1997). At the opposite side of the lec phenotypes, a null mutation in the $P K L$ gene induces embryonic characteristics in the roots of Arabidopsis seedlings, including accumulation of lipids and seed storage proteins normally found in seeds (Ogas et al. 1999; Rider et al. 2004). When excised and cultured on a medium lacking PGR, roots of $p k l$ seedlings spontaneously develop somatic embryos. Exogenous application of GA is sufficient 
to suppress the mutant phenotype, whereas decreasing the level of GA in germinating seeds increases significantly the penetrance of the $p k l$ root phenotype (Ogas et al. 1997). These observations suggest that $P K L$ functions in a GA pathway that controls the switch of root cells from an embryonic to a vegetative fate. The $P K L$ gene encodes a CHD3-chromatin remodeling factor, and thus is likely to function as a negative regulator of transcription of embryo-specific genes (Eshed et al. 1999; Ogas et al. 1999). This is supported by the observation that LEC1 and LEC2 expression levels are significantly higher in $p k l$ than in wild-type seedlings. Thus, expression of embryonic traits in $p k l$ seedlings is highly suspected to be a consequence of the failure to repress expression, in a GA-dependent manner, of the master regulators of embryogenic identity, such as the $L E C$ genes, during germination (Rider et al. 2003). However, as noted by Henderson et al. (2004), data that demonstrate a direct link between $P K L$ activity and GA are still missing and thus it could not be absolutely decided whether repression of $L E C 1$ is or is not a GA-dependent event. The observation that GA can act in the absence of $P K L$ to repress expression of the $p k l$ root phenotype (Ogas et al. 1997) demonstrates that there also exists a $P K L$-independent pathway by which GA represses expression of embryonic traits. This is consistent with the recent metabolic analysis that revealed that pkl Arabidopsis roots accumulate some but not all seed-specific metabolites (Rider et al. 2004).

\section{5}

\section{The WUSCHEL Gene}

Using a genetic approach to identify gain-of-function mutations that can promote embryogenic callus formation from Arabidopsis root explants, Zuo et al. (2002) identified a gene, PAG6, that was found to be identical to WUSCHEL (WUS), a gene previously characterized as a key regulator for specification of stem cell fate in floral and shoot meristems (Laux et al. 1996). WUS encodes a homeodomain protein and is expressed in a small group of cells, namely, the organizing center, below the shoot meristem central zone, which contains the stem cells (Mayer et al. 1998; Schoof et al. 2000).

Overexpression of WUS induces the formation of highly embryogenic callus in the presence of auxin (Zuo et al. 2002). In addition, ectopic overexpression of WUS in transgenic plants directly induces somatic embryos from various vegetative tissues independently of any external PGR treatment. Therefore, WUS appears to be able to trigger the vegetative-to-embryogenic transition, bypassing the auxin requirement or taking advantage of the endogenous auxin flux (Zuo et al. 2002).

Interestingly, WUS cannot reprogram the shoot apex towards SE when overexpressed under the control of meristem-specific promoters such as CLV1, ANT (Schoof et al. 2000), LFY, AP3 and AG (Lenhard et al. 2001; 
Lohmann et al. 2001). This raises the possibility that some factors could favor one or the other WUS function (a shoot meristem or an embryo organizer). Gallois et al. (2004) addressed this possibility by studying the effects of ectopic expression of WUS in roots. In the absence of additional cues, WUS expression in the root induced shoot stem identity and leaf development indicating that WUS establishes stem cells with an intrinsic shoot identity. However, when WUS is coexpressed with $L E A F Y$, which is a master regulator of floral development (Weigel et al. 1992), WUS induces the formation of floral tissues. Finally, when exogenous auxin is supplied, the expression of WUS leads to the development of somatic embryos. This elegant work demonstrates that although WUS expression specifies an intrinsic shoot activity (in the absence of additional cues) it also makes cells developmentally flexible and able to be directed to floral organ or embryo development, depending on additional cues.

\section{6}

\section{Concluding Remarks}

PGRs/PHs are largely used to elicit in vitro SE and are therefore suspected to play important roles in this process; however, the question of their exact function remains open. One difficulty in elucidating the role of PGRs/PHs in SE is that they are likely to be involved at different levels. Although they are very efficient stimuli, they also represent signaling molecules that are an integral part of the molecular pathways underlying SE. As exogenous stimuli, they can occasionally be replaced by other treatments, including stresses such as osmotic or heat shock (Jiménez and Thomas, this volume). In contrast, it becomes obvious that endogenous PHs play essential roles in directing crucial SE-related events, including reentry into the cell cycle and dedifferentiation and redifferentiation of somatic cells. Recent developments in the elucidation of modes of action of PHs have shown that they trigger profound modifications in cellular gene expression patterns both by influencing chromatin structure and DNA methylation and by a finer and more specific transcriptional regulation of target genes.

Recent data suggest that the cellular embryonic competence is "actively" repressed in postembryonic plant tissues by proteins such as AMP1 or PICKLE. Derepression, e.g., by null mutation in repressor genes, opens the way to SE. However, somatic embryo induction is only activated when local tissue/cellular conditions, such as a proper hormonal balance, are appropriate. This would explain why all cells of pickle or amp1 mutants do not uniformly enter an embryonic developmental program. The observation that different mutations induce similar embryonic phenotypes in postembryonic plants reflects the complexity of SE and the possible existence of overlapping pathways triggering this developmental process. 
In recent years functional genomics allowed identification of several potential candidate genes that may be responsible for the establishment of the SE program. Although the participation of these genes in the induction of SE in wild-type plants has not been proved yet, they represent very exciting tracks to pursue in the exploration of molecular pathways underlying SE.

\section{References}

Banno H, Ikeda Y, Niu QW, Chua NH (2001) Overexpression of Arabidopsis ESR1 induces initiation of shoot regeneration. Plant Cell 13:2609-2618

Barbier-Brygoo H, Ephritkhine G, Klämbt D, Ghislain M, Guern J (1989) Functional evidence for an auxin receptor at the plasmalemma of tobacco mesophyll protoplasts. Proc Natl Acad Sci USA 86:891-895

Bardini M, Labra M, Winfield M, Sala F (2003) Antibiotic-induced DNA methylation changes in calluses of Arabidopsis thaliana. Plant Cell Tissue Organ Cult 72:157-162

Baudino S, Hansen S, Brettschneider R, Hecht VF, Dresselhaus T, Lörz H, Dumas C, Rogowsky PM (2001) Molecular characterisation of two novel maize LRR receptor-like kinases, which belong to the SERK gene family. Planta 213:1-10

Bauly JM, Sealy IM, Macdonald H, Brearley J, Droge S, Hillmer S, Robinson DG, Venis MA, Blatt MR, Lazarus CM, Napier RM (2000) Overexpression of auxin-binding protein enhances the sensitivity of guard cells to auxin. Plant Physiol 124:1229-1238

Boutilier K, Offringa R, Sharma VK, Kieft H, Ouellet T, Zhang L, Hattori J, Liu CM, van Lammeren AA, Miki BL, Custers JB, van Lookeren Campagne MM (2002) Ectopic expression of $B A B Y B O O M$ triggers a conversion from vegetative to embryonic growth. Plant Cell 14:1737-1749

Caplan A, Berger PH, Naderi M (1998) Phenotypic variation between transgenic plants: what is making gene expression unpredictable? In: Jain SM, Brar DS, Ahloowalia BS (eds) Somaclonal variation and induced mutations in crop improvement. Kluwer, Dordrecht, pp 539-562

Chang C, Kwok SF, Bleecker AB, Meyerowitz EM (1993) Arabidopsis ethylene-response gene ETR1: similarity of product to two-component regulators. Science 262:539-544

Chen JG, Shimomura S, Sitbon F, Sandberg G, Jones AM (2001a) The role of auxinbinding protein 1 in the expansion of tobacco leaf cells. Plant J 28:607-617

Chen JG, Ullah H, Young JC, Sussman MR, Jones AM (2001b) ABP1 is required for organized cell elongation and division in Arabidopsis embryogenesis. Genes Dev 15:902-911

Custers JBM, Cordewener JHG, Nöllen Y, Dons JJM, van Lookeren Campagne MM (1994) Temperature controls both gametophytic and sporophytic development in microspore cultures of Brassica napus. Plant Cell Rep 13:267-271

De Veylder L, Joubes J, Inze D (2003) Plant cell cycle transitions. Curr Opin Plant Biol 6:536-543

del Pozo JC, Lopez-Matas MA, Ramirez-Parra E, Gutierrez C (2005) Hormonal control of the plant cell cycle. Physiol Plant 123:173-183

Dewitte W, Murray JA (2003) The plant cell cycle. Annu Rev Plant Biol 54:235-264

Dharmasiri S, Estelle M (2002) The role of regulated protein degradation in auxin response. Plant Mol Biol 49:401-409

Dudits D, Bögre L, Györgyey J (1991) Molecular and cellular approaches to the analysis of plant embryo development from somatic cells in vitro. J Cell Sci 99:475-484 
Dudits D, Györgyey J, Bögre L, Bakó L (1995) Molecular biology of somatic embryogenesis. In: Thorpe TA (ed) In Vitro embryogenesis in plants. Kluwer, Dordrecht, pp 276-308

Eshed Y, Baum SF, Bowman JL (1999) Distinct mechanisms promote polarity establisment in carpels of Arabidopsis. Cell 99:199-209

Fehér A, Pasternak T, Dudits D (2003) Transition of somatic plant cells to an embryogenic state. Plant Cell Tissue Organ Cult 74:201-228

Finkelstein RR, Wang ML, Lynch TJ, Rao S, Goodman HM (1998) The Arabidopsis abscisic acid response locus ABI4 encodes an APETALA 2 domain protein. Plant Cell 10:1043-1054

Francis D, Sorrell DA (2001) The interface between the cell cycle and plant growth regulators: a mini review. Plant Growth Regul 33:1-12

Gallois JL, Nora FR, Mizukami Y, Sablowski R (2004) WUSCHEL induces shoot stem cell activity and developmental plasticity in the root meristem. Genes Dev 18:375-380

Gaspar T, Kevers C, Faivre-Rampant O, Crèvecoeur M, Penel C, Greppin H, Dommes J (2003) Changing concepts in plant hormone action. In Vitro Cell Dev Biol Plant 39:85-105

Gray WM, Kepinski S, Rouse D, Leyser O, Estelle M (2001) Auxin regulates SCF(TIR1)dependent degradation of AUX/IAA proteins. Nature 414:271-276

Gu YQ, Yang C, Thara VK, Zhou J, Martin GB (2000) Pti4 is induced by ethylene and salicylic acid, and its product is phosphorylated by the Pto kinase. Plant Cell 12:771-786

Gubler F, Jacobsen JV (1992) Gibberellin-responsive elements in the promoter of a barley high-pI alpha-amylase gene. Plant Cell 4:1435-1441

Guilfoyle T, Hagen G, Ulmasov T, Murfett J (1998) How does auxin turn on genes? Plant Physiol 118:341-347

Hagen G, Guilfoyle T (2002) Auxin-responsive gene expression: genes, promoters and regulatory factors. Plant Mol Biol 49:373-385

Hecht V, Vielle-Calzada JP, Hartog MV, Schmidt ED, Boutilier K, Grossniklaus U, de Vries SC (2001) The Arabidopsis SOMATIC EMBRYOGENESIS RECEPTOR KINASE 1 gene is expressed in developing ovules and embryos and enhances embryogenic competence in culture. Plant Physiol 127:803-816

Hemerly AS, Ferreira P, de Almeida Engler J, Van Montagu M, Engler G, Inze D (1993) $c d c 2 a$ expression in Arabidopsis is linked with competence for cell division. Plant Cell 5:1711-1723

Henderson JT, Li HC, Rider SD, Mordhorst AP, Romero-Severson J, Cheng JC, Robey J, Sung ZR, de Vries SC, Ogas J (2004) PICKLE acts throughout the plant to repress expression of embryonic traits and may play a role in gibberellin-dependent responses. Plant Physiol 134:995-1005

Hirt H, Pay A, Györgyey J, Bako L, Nemeth K, Bogre L, Schweyen RJ, Heberle-Bors E, Dudits D (1991) Complementation of a yeast cell cycle mutant by an alfalfa cDNA encoding a protein kinase homologous to p34cdc2. Proc Natl Acad Sci USA 88:1636-1640

Inohara N, Shimomura S, Fukui T, Futai M (1989) Auxin-binding protein located in the endoplasmic reticulum of maize shoots: molecular cloning and complete primary structure. Proc Natl Acad Sci USA 86:3564-3568

Inoue T, Higuchi M, Hashimoto Y, Seki M, Kobayashi M, Kato T, Tabata S, Shinozaki K, Kakimoto T (2001) Identification of CRE1 as a cytokinin receptor from Arabidopsis. Nature 409:1060-1063

Jiménez VM (2001) Regulation of in vitro somatic embryogenesis with emphasis on the role of endogenous hormones. Rev Bras Fisiol Veg 13:196-223

John PCL, Zhang K, Dongg C, Diederich L, Wightman F (1993) A p34cdc2 related protein in control of cell cycle progression, the switch between division and differentiation in 
tissue development and stimulation of division by auxin and cytokinin. Aust J Plant Physiol 20:503-526

Jones AM, Im KH, Savka MA, Wu MJ, DeWitt NG, Shillito R, Binns AN (1998) Auxindependent cell expansion mediated by overexpressed auxin-binding protein 1 . Science 282:1114-1117

Kitamiya E, Suzuki S, Sano T, Nagata T (2000) Isolation of two genes that were induced upon the initiation of somatic embryogenesis on carrot hypocotyls by high concentrations of 2,4-D. Plant Cell Rep 19:551-557

Klucher KM, Chow H, Reiser L, Fischer RL (1996) The AINTEGUMENTA gene of Arabidopsis required for ovule and female gametophyte development is related to the floral homeotic gene APETALA2. Plant Cell 8:137-153

Kulaeva ON, Prokoptseva OS (2004) Recent advances in the study of mechanisms of action of phytohormones. Biochemistry (Moscow) 69:233-247

Laureys F, Dewitte W, Witters E, Van Montagu M, Inze D, Van Onckelen H (1998) Zeatin is indispensable for the G2-M transition in tobacco BY-2 cells. FEBS Lett 426:29-32

Laux T, Mayer KF, Berger J, Jurgens G (1996) The WUSCHEL gene is required for shoot and floral meristem integrity in Arabidopsis. Development 122:87-96

Leblanc N, David K, Grosclaude J, Pradier JM, Barbier-Brygoo H, Labiau S, PerrotRechenmann C (1999) A novel immunological approach establishes that the auxinbinding protein, $\mathrm{Nt}-\mathrm{abp} 1$, is an element involved in auxin signaling at the plasma membrane. J Biol Chem 274:28314-28320

Lenhard M, Bohnert A, Jurgens G, Laux T (2001) Termination of stem cell maintenance in Arabidopsis floral meristems by interactions between WUSCHEL and AGAMOUS. Cell 105:805-814

Li G, Hall TC, Holmes-Davis R (2002) Plant chromatin: development and gene control. Bioassays 24:234-243

Lin X, Hwang GJ, Zimmerman JL (1996) Isolation and characterization of a diverse set of genes from carrot somatic embryos. Plant Physiol 112:1365-1374

Lohmann JU, Hong RL, Hobe M, Busch MA, Parcy F, Simon R, Weigel D (2001) A molecular link between stem cell regulation and floral patterning in Arabidopsis. Cell 105:793-803

Lotan T, Ohto M, Yee KM, West MA, Lo R, Kwong RW, Yamagishi K, Fischer RL, Goldberg RB, Harada JJ (1998) Arabidopsis LEAFY COTYLEDON1 is sufficient to induce embryo development in vegetative cells. Cell 93:1195-1205

Luerssen H, Kirik V, Herrmann P, Misera S (1998) FUSCA3 encodes a protein with a conserved VP1/AB13-like B3 domain which is of functional importance for the regulation of seed maturation in Arabidopsis thaliana. Plant J 15:755-764

Marcotte WR Jr, Guiltinan MJ, Quatrano RS (1992) ABA-regulated gene expression: cisacting sequences and trans-acting factors. Biochem Soc Trans 20:93-97

Martinez MC, Jorgensen JE, Lawton MA, Lamb CJ, Doerner PW (1992) Spatial pattern of $c d c 2$ expression in relation to meristem activity and cell proliferation during plant development. Proc Natl Acad Sci USA 89:7360-7364

Mayer KF, Schoof H, Haecker A, Lenhard M, Jurgens G, Laux T (1998) Role of WUSCHEL in regulating stem cell fate in the Arabidopsis shoot meristem. Cell 95:805-815

McCarty DR, Carson CB, Stinard PS, Robertson DS (1989) Molecular analysis of viviparous-1: an abscisic acid-insensitive mutant of maize. Plant Cell 1:523-532

McCarty DR, Hattori T, Carson CB, Vasil V, Lazar M, Vasil IK (1991) The viviparous-1 developmental gene of maize encodes a novel transcriptional activator. Cell 66:895-905

Meinke DW, Franzmann LH, Nickle TC, Yeung EC (1994) Leafy cotyledon mutants of Arabidopsis. Plant Cell 6:1049-1064 
Meller Y, Sessa G, Eyal Y, Fluhr R (1993) DNA-protein interactions on a cis-DNA element essential for ethylene regulation. Plant Mol Biol 23:453-463

Menke FL, Champion A, Kijne JW, Memelink J (1999) A novel jasmonate- and elicitorresponsive element in the periwinkle secondary metabolite biosynthetic gene Str interacts with a jasmonate- and elicitor-inducible AP2-domain transcription factor, ORCA2. EMBO J 18:4455-4463

Miao GH, Hong Z, Verma DP (1993) Two functional soybean genes encoding p34cdc2 protein kinases are regulated by different plant developmental pathways. Proc Natl Acad Sci USA 90:943-947

Mordhorst AP, Voerman KJ, Hartog MV, Meijer EA, van Went J, Koornneef M, de Vries SC (1998) Somatic embryogenesis in Arabidopsis thaliana is facilitated by mutations in genes repressing meristematic cell divisions. Genetics 149:549-563

Nagata T, Ishida S, Hasezawa S, Takahashi Y (1994) Genes involved in the dedifferentiation of plant cells. Int J Dev Biol 38:321-327

Nakano Y, Steward N, Sekine M, Kusano T, Sano H (2000) A tobacco NtMET1 cDNA encoding a DNA methyltransferase: molecular characterization and abnormal phenotypes of transgenic tobacco plants. Plant Cell Physiol 41:448-457

Nolan KE, Irwanto RR, Rose RJ (2003) Auxin up-regulates MtSERK1 expression in both root-forming and embryogenic cultures. Plant Physiol 133:218-230

Ogas J, Cheng JC, Sung ZR, Somerville C (1997) Cellular differentiation regulated by gibberellin in the Arabidopsis thaliana pickle mutant. Science 277:91-94

Ogas J, Kaufmann S, Henderson J, Somerville C (1999) PICKLE is a CHD3 chromatinremodeling factor that regulates the transition from embryonic to vegetative development in Arabidopsis. Proc Natl Acad Sci USA 96:13839-13844

Redig P, Shaul O, Inze D, Van Montagu M, Van Onckelen H (1996) Levels of endogenous cytokinins, indole-3-acetic acid and abscisic acid during the cell cycle of synchronized tobacco BY-2 cells. FEBS Lett 391:175-180

Rider SD Jr, Henderson JT, Jerome RE, Edenberg HJ, Romero-Severson J, Ogas J (2003) Coordinate repression of regulators of embryonic identity by PICKLE during germination in Arabidopsis. Plant J 35:33-43

Rider SD Jr, Hemm MR, Hostetler HA, Li HC, Chapple C, Ogas J (2004) Metabolic profiling of the Arabidopsis pkl mutant reveals selective derepression of embryonic traits. Planta 219:489-499

Riechmann JL, Meyerowitz EM (1998) The AP2/EREBP family of plant transcription factors. Biol Chem 379:633-646

Riou-Khamlichi C, Huntley R, Jacqmard A, Murray JA (1999) Cytokinin activation of Arabidopsis cell division through a D-type cyclin. Science 283:1541-1544

Roudier F, Fedorova E, Lebris M, Lecomte P, Györgyey J, Vaubert D, Horvath G, Abad P, Kondorosi A, Kondorosi E (2003) The Medicago species A2-type cyclin is auxin regulated and involved in meristem formation but dispensable for endoreduplicationassociated developmental programs. Plant Physiol 131:1091-1103

Rück A, Palme K, Venis MA, Napier R, Felle RH (1993) Patch-clamp analysis establishes a role for an auxin binding protein in the auxin stimulation of plasma membrane current in Zea mays protoplasts. Plant J 4:41-46

Satoh S, Kamada H, Harada H, Fujii T (1986) Auxin-controlled glycoprotein release into the medium of embryogenic carrot cells. Plant Physiol 81:931-933

Sauter M (1997) Differential expression of a CAK (cdc2-activating kinase)-like protein kinase, cyclins and cdc2 genes from rice during the cell cycle and in response to gibberellin. Plant J 11:181-190 
Schaller GE, Bleecker AB (1995) Ethylene-binding sites generated in yeast expressing the Arabidopsis ETR1 gene. Science 270:1809-1811

Schmidt ED, Guzzo F, Toonen MA, de Vries SC (1997) A leucine-rich repeat containing receptor-like kinase marks somatic plant cells competent to form embryos. Development 124:2049-2062

Schoof H, Lenhard M, Haecker A, Mayer KF, Jurgens G, Laux T (2000) The stem cell population of Arabidopsis shoot meristems in maintained by a regulatory loop between the CLAVATA and WUSCHEL genes. Cell 100:635-644

Shimomura S, Watanabe S, Hiroaki I (1999) Characterization of auxin-binding protein 1 from tobacco: content, localization and auxin-binding activity. Planta 209:118-125

Somleva MN, Schmidt EDL, de Vries SC (2000) Embryogenic cells in Dactylis glomerata L. (Poaceae) explants identified by cell tracking and by SERK expression. Plant Cell Rep 19:718-726

Stals H, Inze D (2001) When plant cells decide to divide. Trends Plant Sci 6:359-364

Steffens B, Feckler C, Palme K, Christian M, Bottger M, Luthen H (2001) The auxin signal for protoplast swelling is perceived by extracellular ABP1. Plant J 27:591-599

Stone SL, Kwong LW, Yee KM, Pelletier J, Lepiniec L, Fischer RL, Goldberg RB, Harada JJ (2001) LEAFY COTYLEDON2 encodes a B3 domain transcription factor that induces embryo development. Proc Natl Acad Sci USA 98:11806-11811

Swiatek A, Lenjou M, Van Bockstaele D, Inze D, Van Onckelen H (2002) Differential effect of jasmonic acid and abscisic acid on cell cycle progression in tobacco BY-2 cells. Plant Physiol 128:201-211

Takahashi Y, Kuroda H, Tanaka T, Machida Y, Takebe I, Nagata T (1989) Isolation of an auxin-regulated gene cDNA expressed during the transition from G0 to $\mathrm{S}$ phase in tobacco mesophyll protoplasts. Proc Natl Acad Sci USA 86:9279-9283

Thiel G, Blatt MR, Fricker MD, White IR, Millner P (1993) Modulation of $\mathrm{K}^{+}$channels in Vicia stomatal guard cells by peptide homologs to the auxin-binding protein $\mathrm{C}$ terminus. Proc Natl Acad Sci USA 90:11493-11497

Thomas C, Bronner R, Molinier J, Prinsen E, van Onckelen H, Hahne G (2002) Immunocytochemical localization of indole-3-acetic acid during induction of somatic embryogenesis in cultured sunflower embryos. Planta 215:577-583

Thomas C, Meyer D, Himber C, Steinmetz A (2004) Spatial expression of a sunflower SERK gene during induction of somatic embryogenesis and shoot organogenesis. Plant Physiol Biochem 42:35-42

Thomas TL (1993) Gene expression during plant embryogenesis and germination: An overview. Plant Cell 5:1401-1410

Tiwari SB, Wang XJ, Hagen G, Guilfoyle TJ (2001) AUX/IAA proteins are active repressors, and their stability and activity are modulated by auxin. Plant Cell 13:2809-2822

Ueguchi C, Sato S, Kato T, Tabata S (2001) The AHK4 gene involved in the cytokininsignaling pathway as a direct receptor molecule in Arabidopsis thaliana. Plant Cell Physiol 42:751-755

Ulmasov T, Hagen G, Guilfoyle TJ (1999) Activation and repression of transcription by auxin-response factors. Proc Natl Acad Sci USA 96:5844-5849

van der Fits L, Memelink J (2001) The jasmonate-inducible AP2/ERF-domain transcription factor ORCA3 activates gene expression via interaction with a jasmonateresponsive promoter element. Plant J 25:43-53

Wang H, Qi Q, Schorr P, Cutler AJ, Crosby WL, Fowke LC (1998) ICK1, a cyclin-dependent protein kinase inhibitor from Arabidopsis thaliana interacts with both Cdc2a and CycD3, and its expression is induced by abscisic acid. Plant J 15:501-510 
Weigel D, Alvarez J, Smyth DR, Yanofsky MF, Meyerowitz EM (1992) LEAFY controls floral meristem identity in Arabidopsis. Cell 69:843-859

West M, Yee KM, Danao J, Zimmerman JL, Fischer RL, Goldberg RB, Harada JJ (1994) LEAFY COTYLEDON1 is an essential regulator of late embryogenesis and cotyledon identity in Arabidopsis. Plant Cell 6:1731-1745

Worley CK, Zenser N, Ramos J, Rouse D, Leyser O, Theologis A, Callis J (2000) Degradation of Aux/IAA proteins is essential for normal auxin signaling. Plant J 21:553-562

Yamamoto N, Kobayashi H, Togashi T, Mori Y, Kikuchi K, Kuriyama K, Tokuji Y (2005) Formation of embryogenic cell clumps from carrot epidermal cells is suppressed by 5-azacytidine, a DNA methylation inhibitor. J Plant Physiol 162:47-54

Yasuda H, Nakajima M, Ito T, Ohwada T, Masuda H (2001) Partial characterization of genes whose transcripts accumulate preferentially in cell clusters at the earliest stage of carrot somatic embryogenesis. Plant Mol Biol 45:705-712

Yazawa K, Takahata K, Kamada H (2004) Isolation of the gene encoding Carrot leafy cotyledon 1 and expression analysis during somatic and zygotic embryogenesis. Plant Physiol Biochem 42:215-223

Yeung EC (1995) Structural and developmental patterns in somatic embryogenesis. In: Thorpe TA (ed) In vitro Embryogenesis in Plants. Kluwer Academic Publishers, Dordrecht, p 205-248

Zhang K, Letham DS, John PC (1996) Cytokinin controls the cell cycle at mitosis by stimulating the tyrosine dephosphorylation and activation of p34cdc2-like $\mathrm{H} 1$ histone kinase. Planta 200:2-12

Zhao J, Morozova N, Williams L, Libs L, Avivi Y, Grafi G (2001) Two phases of chromatin decondensation during dedifferentiation of plant cells: distinction between competence for cell fate switch and a commitment for S phase. J Biol Chem 276:22772-22778

Zimmerman JL, Thomine S, Guern J, Barbier-Brygoo H (1994) An anion current at the plasma

Zuo J, Niu QW, Frugis G, Chua NH (2002) The WUSCHEL gene promotes vegetative-toembryonic transition in Arabidopsis. Plant J 30:349-359 